\title{
Pendapatan Daerah, Pembiayaan Kesehatan, dan Gizi Buruk pada Balita: Studi Korelasi Tingkat Kabupaten/Kota
}

\author{
Local Government Revenue, Health Financing, and Severely Wasted: \\ the Correlational Study at District Level
}

\author{
Septyana Choirunisa, Asri C. Adisasmita
}

Departemen Epidemiologi Fakultas Kesehatan Masyarakat Universitas Indonesia

\begin{abstract}
Abstrak
Pendanaan kesehatan merupakan salah satu faktor penting dalam memengaruhi derajat kesehatan, termasuk salah satu masalah gizi pada balita yang disebut gizi buruk. Oleh karena itu, penelitian ini bertujuan mendeskripsikan pendapatan daerah dan pembiayaan kesehatan serta korelasinya dengan gizi buruk pada balita di tingkat kabupaten/kota di Indonesia tahun 2007. Penelitian ini merupakan studi ekologi/korelasi. Data pendapatan daerah dan pembiayaan kesehatan didapat dari Kementerian Keuangan, sedangkan data gizi buruk menggunakan data Riset Kesehatan Nasional tahun 2007. Sebanyak 250 kabupaten/kota yang diteliti dengan tidak mengikutsertakan kabupaten/kota yang datanya tidak lengkap atau tidak valid. Secara nasional, hanya persentase pendapatan asli daerah (PAD) per total pendapatan yang berkorelasi dengan gizi buruk, meskipun korelasinya lemah $(r=0,22)$. Berdasarkan kawasan di Indonesia, Kawasan Indonesia Barat dan Kawasan Indonesia Timur menunjukkan persentase PAD per total pendapatan berkorelasi lemah dengan gizi buruk $(r=0,20$ dan $r=0,53$ ). Terlihat kecenderungan bahwa semakin tinggi persentase pendapatan daerah dan pembiayaan kesehatan, semakin rendah persentase gizi buruknya. Korelasi antara pendapatan daerah, pembiayaan kesehatan dan masalah status gizi tidak dapat diabaikan. Data yang lebih lengkap dan valid diperlukan untuk dikembangkan penelitian selanjutnya.

Kata kunci: Gizi buruk, pembiayaan kesehatan, pendapatan daerah
\end{abstract}

\footnotetext{
Abstract

Health financing is one of the factors which contribute important role in influencing health status, including nutritional problem among children under five, called severely wasted. Therefore, the aim of this study was to describe districts income and health financing and examine it correlations with the prevalence of severely wasted among children under 5 years at regencies/municipalities level in Indonesia in 2007. This research was an ecological study. Data on revenue and health financing were obtained from Ministry of Finance, and severely wasted data were obtained from the
}

Indonesian Basic Health Research (Riskesdas) 2007. There are 250 regencies/municipalities were being objects of this research, while the others were excluded due to incomplete/missing or invalid data. Result shows nationally, only the percentage of local revenue by total district income had correlation with severely wasted, although it is weak $(r=0,22)$. By regions, in the Western Region Indonesia and the Eastern Region Indonesia, those variable had weak correlation with severely wasted $(r=0,20$ and $r=0,53)$. The graphics trend shows higher percentage of local revenue and health financing, related to lower number of the prevalence of severely wasted. The correlation between district income and health financing for poor nutritional status cannot be ruled out. More valid and complete data on district income and health financing is needed for further research.

Keywords: Severely wasted, health financing, local revenue

\section{Pendahuluan}

Di dunia, salah satu gangguan gizi pada balita yang masih menjadi perhatian adalah underweight, stunting, dan wasting. Diperkirakan, prevalensi tertinggi untuk ketiga gangguan gizi tersebut lebih banyak terdapat di kawasan Asia Tenggara, Asia Selatan, dan Sub-Sahara Afrika. ${ }^{1}$ Di Indonesia, istilah gangguan gizi pada balita yang lebih sering dipakai adalah gizi buruk, yaitu wasting atau berat badan banding tinggi badan. ${ }^{2}$

Berdasarkan hasil Riset Kesehatan Dasar (Riskesdas) tahun 2007, tiga provinsi dengan prevalensi gizi buruk tertinggi yaitu NAD (10,7\%), Sulawesi Barat (10\%), dan NTT $(9,4 \%)$. Untuk tingkat kabupaten/kota, yang prevalensi gizi buruknya tertinggi secara nasional adalah

Korespondensi: Asri C. Adisasmita, Departemen Epidemiologi Gd. A Lt. 1 Fakultas Kesehatan Masyarakat Universitas Indonesia, Kampus Baru UI Depok 16424, Hp.08121355297, e-mail: aadsmt237@gmail.com 
Kab. Seruyan $(26,20 \%)$ di Kalimantan Tengah, Kab. Solok Selatan $(21,40 \%)$ di Sumatra Barat, dan Kab. Manggarai $(19,60 \%)$ di NTT. ${ }^{3}$

Gizi buruk merupakan masalah yang menjadi perhatian karena tidak hanya berdampak pada jangka pendek seperti menyebabkan bayi atau balita rentan terhadap penyakit-penyakit infeksi, ketahanan hidup rendah, IQ rendah, kemampuan kognitif rendah dan juga kematian tetapi juga berdampak pada jangka panjang yaitu memengaruhi kecerdasan calon generasi penerus, kualitas dan produktivitas sumber daya manusia. ${ }^{4-7}$ Gizi buruk dapat dipengaruhi oleh banyak penyebab, mulai penyebab langsung sampai akar penyebab di tingkat masyarakat dan nasional. Mulai dari makanan tidak seimbang dan penyakit infeksi, hingga pengangguran, inflasi, kemiskinan, krisis ekonomi-politik-sosial, angka pertumbuhan ekonomi dan persentase anggaran pemerintah untuk sektor kesehatan dan pendidikan. ${ }^{8}$

Dalam suatu sistem input-process-output-outcome dalam framework World Health Organization (WHO), status gizi balita termasuk dalam salah satu outputnya, peran pendanaan kesehatan dianggap merupakan salah satu input yang penting dalam mewujudkan derajat kesehatan. ${ }^{9,10}$ Sementara, di Indonesia yang sejak tahun 2001 menggunakan sistem desentralisasi (kabupaten/kota mengatur wilayahnya secara mandiri), perbedaan dalam hal pendanaan kesehatan karena perbedaan kemampuan, sumber pendanaan dan prioritas antarprovinsi dan antarkabupaten/kota semakin terlihat. Pendanaan kesehatan tersebut digambarkan dalam persentase pembiayaan kesehatan per total belanja dan persentase pembiayaan kesehatan per total pendapatan. Selain perbedaan kemampuan dalam pembiayaan kesehatan, juga terjadi kesenjangan status kesehatan antardaerah. ${ }^{10,11}$

Oleh karena perbedaan pembiayaan dan status kesehatan (termasuk status gizi balita) antarkabupaten, penelitian ini bertujuan untuk menggambarkan pendapatan daerah, pembiayaan kesehatan, serta korelasinya dengan gizi buruk pada tingkat kabupaten/kota, yang diharapkan dapat digunakan sebagai referensi gambaran pembiayaan dan status kesehatan di Indonesia.

\section{Metode}

Desain studi dalam penelitian ini adalah studi korelasi yang bersifat deskriptif. ${ }^{12}$ Aspek yang diteliti meliputi kemampuan daerah yang digambarkan dalam variabel Persentase Pendapatan Asli Daerah terhadap Total Pendapatan (PADTP). Pembiayaan kesehatan yang digambarkan dalam persentase pembiayaan kesehatan bersumber pemerintah mencakup Persentase Pembiayaan Kesehatan terhadap Total Belanja (PKTB) dan Pembiayaan Kesehatan terhadap Total Pendapatan (PKTP). Status kesehatan yang diteliti dalam penelitian ini adalah prevalensi gizi buruk pada tingkat kabupa- ten/kota.

Populasi studi yaitu seluruh kabupaten/kota di Indonesia. Kriteria inklusinya yaitu seluruh kabupaten/kota yang data APBD-nya dilaporkan ke Dirjen Perimbangan Keuangan, Kementerian Kesehatan RI. Kriteria eksklusinya, yaitu kabupaten/kota yang datanya tidak lengkap/'missing' pada salah satu variabel (total pendapatan, PAD, total belanja atau pembiayaan kesehatan); kabupaten/kota yang persentase total pendapatan terhadap total belanjanya $\leq 35 \%$; kabupaten/kota yang pendapatan dibandingkan pengeluarannya mengalami defisit $>5 \%$ (mengacu pada batas minimal defisit APBD menurut Bab III Pasal IV Peraturan Menkeu No.72/PMK, 02/2006). ${ }^{13}$ Hal tersebut dilakukan untuk menghindari penggunaan data yang tidak valid sehingga berdasarkan kriteria insklusi dan eksklusi, sebanyak 250 kabupaten/kota yang diikutsertakan dalam penelitian dari total 435 kabupaten/kota yang ada di Indonesia.

Data gizi yang digunakan adalah prevalensi gizi buruk tiap kabupaten/kota yang diperoleh dari Laporan Hasil Riskesdas Provinsi tahun 2007.3 Gizi buruk (severly wasted) dihitung berdasarkan BB/TB balita. 2,14 Indikator ini menunjukkan kesakitan akut pada balita atau kurangnya asupan makanan yang terjadi di masa itu (bukan lampau seperti stunting). ${ }^{14}$ Oleh karena itu, penelitian ini lebih memfokuskan pada gizi buruk, yang menjadi perhatian utama masyarakat dan pengukurannya dapat dipastikan dibandingkan underweight yang akan bias apabila umur balita tidak diketahui. Data yang diperoleh dari laporan APBD provinsi dan kabupaten/kota tahun 2007 yaitu data total pendapatan daerah, pendapatan asli daerah, total belanja daerah, dan belanja daerah yang dirinci ke dalam sektor-sektor (termasuk sektor kesehatan) dalam bentuk rupiah sehingga untuk mendapatkan variabel persentase PADTP dan persentase PKTP dan PKTB perlu dilakukan perhitungan persentase sebelum dianalisis.

Data diolah dengan Arcview GIS versi 3.3 untuk menghasilkan distribusi tiap variabel dalam bentuk peta Indonesia tematik. Analisis data dilakukan untuk mendapatkan gambaran tiap variabel (berdasarkan rata-rata, median, dan nilai minimal-maksimal) dan gambaran korelasi ( $r, \mathrm{R}^{2}$, nilai $\mathrm{p}$, dan diagram tebar) tiap variabel dengan variabel prevalensi gizi buruk. Korelasi yang digunakan adalah korelasi Spearman karena distribusi data tidak normal. ${ }^{12}$ Perhitungan korelasi dilakukan dengan korelasi tiap variabel dengan prevalensi gizi buruk di tingkat kabupaten/kota secara nasional; korelasi tiap variabel dengan prevalensi gizi buruk di tingkat kabupaten/kota berdasarkan tiga wilayah di Indonesia, yaitu Kawasan Indonesia Barat/KIB mencakup pulau SumatraJawa-Bali, Kawasan Indonesia Tengah/KITA mencakup Kalimantan-Sulawesi-Nusa Tenggara, dan Kawasan Indonesia Timur/KIT mencakup Pulau Maluku-Papu se- 
Tabel 1. Ringkasan Mean, Standar Deviasi, dan Nilai Minimal-Maksimal Tiap Variabel

\begin{tabular}{|c|c|c|c|}
\hline Variabel (n kabupaten $/$ kota $=250$ ) & Rata-rata & Median & Minimal-Maksimal \\
\hline Total pendapatan daerah (ratus juta rupiah) & 551,07 & 487,42 & $247,18-2.029,55$ \\
\hline Pendapatan asli daerah (PAD) (ratus juta rupiah) & 42,01 & 22,46 & $4,20-607,64$ \\
\hline Total belanja daerah (ratus juta rupiah) & 525,58 & 453,91 & $225,38-1.799,97$ \\
\hline Pembiayaan kesehatan (ratus juta rupiah) & 45,86 & 41,58 & $5,75-161,31$ \\
\hline$\%$ PAD terhadap total pendapatan daerah (PADTP) & $6,49 \%$ & $5,00 \%$ & $1,25 \%-53,73 \%$ \\
\hline$\%$ Pembiayaan kesehatan per total pendapatan (PKTP) & $8,53 \%$ & $8,45 \%$ & $1,62 \%-20,86 \%$ \\
\hline$\%$ Pembiayaan kesehatan per total belanja (РКTB) & $8,95 \%$ & $8,96 \%$ & $1,63 \%-22,51 \%$ \\
\hline Prevalensi gizi buruk & $6,61 \%$ & $5,90 \%$ & $0,80 \%-26,20 \%$ \\
\hline
\end{tabular}

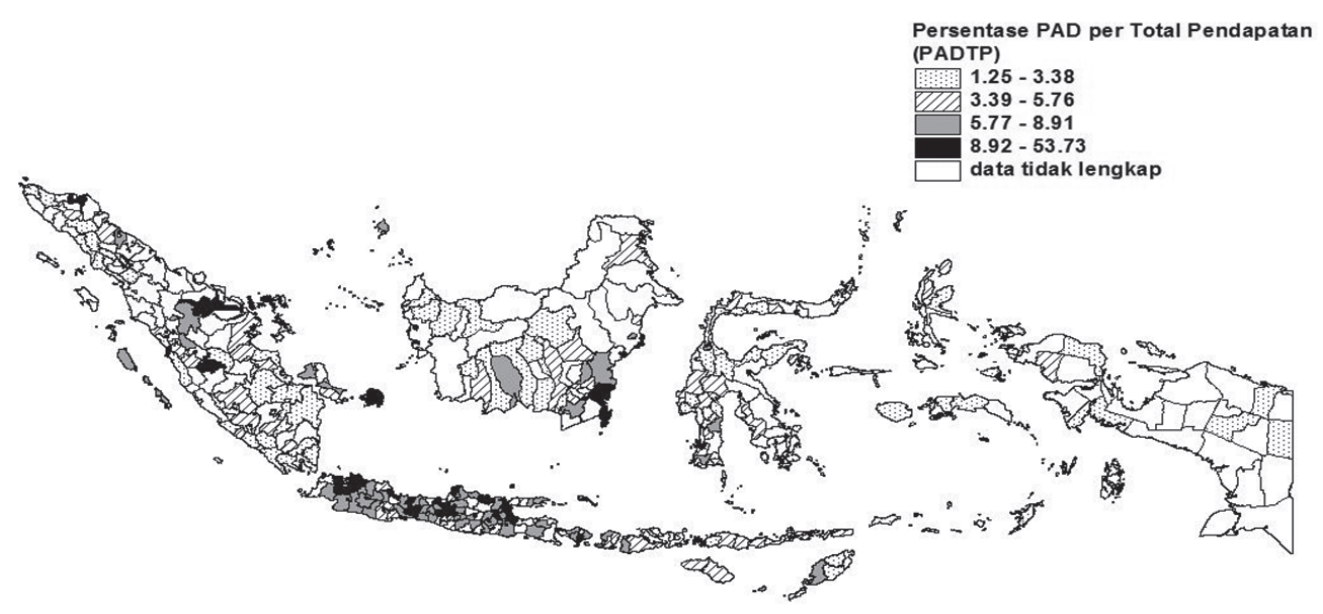

Gambar 1. Distribusi Persentase PAD per Total Pendapatan Kabupaten/Kota di Indonesia

hingga didapatkan gambaran di tingkat kabupaten/kota secara nasional dan di tingkat kabupaten/kota berdasarkan wilayah/kawasan.

\section{Hasil}

Tabel 1 menunjukkan rata-rata, median dan nilai minimal-maksimal semua variabel yang diteliti. Besaran total pendapatan daerah, PAD, total belanja, dan pembiayaan kesehatan juga dicantumkan dalam bentuk ratus juta rupiah. Berdasarkan variabel pada tabel tersebut, terlihat kesenjangan yang besar antar kabupaten/kota. Total pendapatan daerah terbesar yang dimiliki kabupaten/kota merupakan 8 kali lipatnya total pendapatan di daerah terkecil. Persentase PADTP terbesar sekitar 50 kali lebih besar daripada persentase PADTP terkecil. Untuk pembiayaan kesehatan, pembiayaan kesehatan terbesar kabupaten/kota mencapai 28 kali lipat dari pembiayaan kesehatan terkecil kabupaten/kota. Persentase PKTP dan PKTB juga bervariasi, yang terbesar sekitar 20 kali lipat dari persentase PKTP dan PKTB terkecil.

Distribusi persentase PAD per total pendapatan (PADTP) dan prevalensi gizi buruk dikategorikan berdasarkan kuartil (Gambar 1 dan Gambar 2). Sedangkan persentase PKTP dan PKTB dikategorikan menjadi $<5 \%, 5-<10 \%, 10-<15 \%$, dan $15 \%$ atau lebih
(Gambar 2 dan Gambar 3).

Sebanyak $145(56,67 \%)$ dari total 251 kabupaten/kota yang ada di wilayah KIB yang diteliti dalam penelitian ini. Sedangkan untuk kawasan Indonesia Tengah, sebanyak 88 (63,30\%) dari 139 kabupaten/kota di KITA yang datanya dapat digunakan. Untuk wilayah Timur, 17 (37\%) dari 45 kabupaten/kota di KIT yang diteliti dalam penelitian ini. Hasil penelitian ini hanya dapat menggambarkan kondisi kabupaten/kota yang termasuk dalam penelitian atau tidak dapat digeneralisasikan sebagai kondisi di kabupaten/kota diluar area penelitian, meskipun tersebut berada dalam satu kawasan.

Berdasarkan hasil uji korelasi, hanya persentase PADTP yang menunjukkan korelasi yang signifikan dengan prevalensi gizi buruk (Gambar 5). Meskipun korelasi yang ditunjukkan lemah, terdapat kecenderungan arah korelasi yang negatif. Dengan kata lain, semakin tinggi masing-masing variabel tersebut, semakin rendah prevalensi gizi buruknya. Begitu juga halnya berdasarkan tiga kawasan, kecenderungan korelasi bersifat negatif meskipun pada kawasan Indonesia Timur hal ini tidak begitu terlihat.

\section{Pembahasan}

Berdasarkan variabel persentase PADTP, PKTP dan 


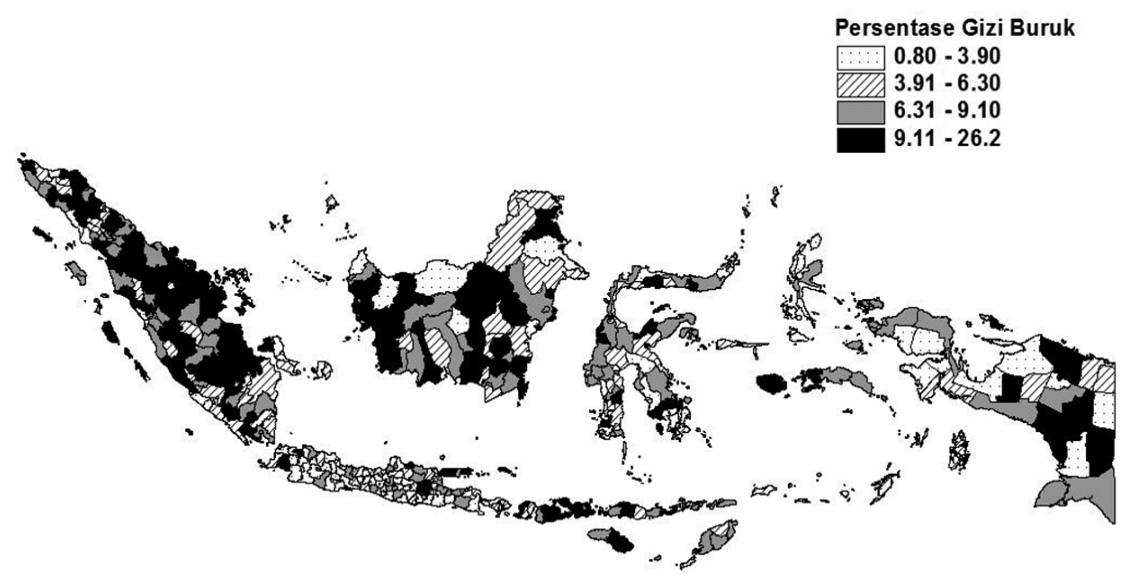

Gambar 2. Distribusi Prevalensi Gizi Buruk Kabupaten/Kota di Indonesia

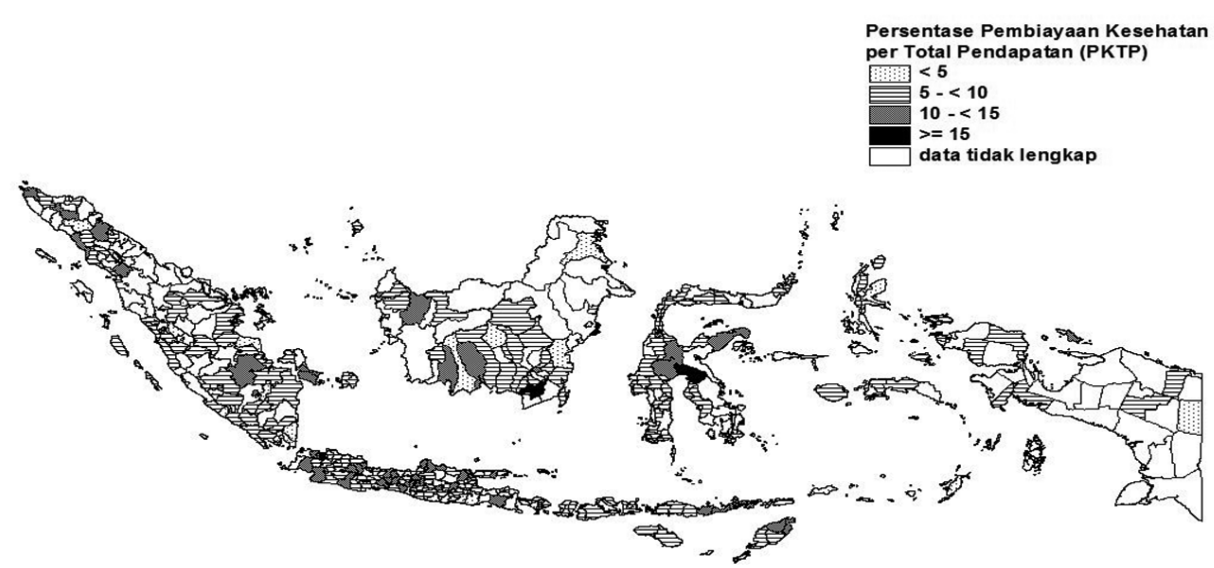

Gambar 3. Distribusi Pembiayaan Kesehatan per Total Pendapatan Kabupaten/Kota di Indonesia

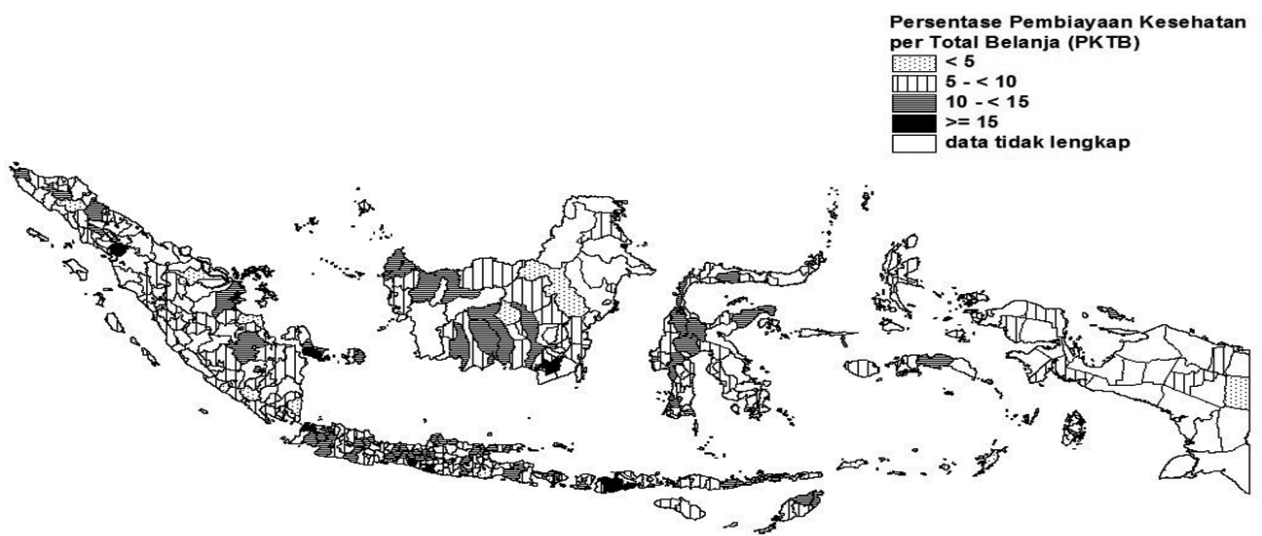

Gambar 4. Distribusi Pembiayaan Kesehatan per Total Belanja Kabupaten/Kota di Indonesia

PKTB pada Tabel 1, terlihat adanya kesenjangan yang besar antarkabupaten/kota. Berdasarkan variabel PADTP, rata-rata persentasenya yaitu 6,49\%. Artinya ketergantungan kabupaten/kota terhadap dana dari pusat maupun provinsi sangat besar. Rentang yang besar pada persentase PADTP antara kabupaten/kota memperlihatkan kesenjangan kemampuan dalam membiayai daerahnya. Hasil tersebut serupa dengan hasil penelitian Heywood dan Harahap (2009) yang menemukan bahwa pendapatan pemerintah daerah bergantung lebih dari
90\% kepada dana pusat dan terjadi kesenjangan pendapatan antardaerah sangat mungkin terjadi akibat perbedaan sumber daya. 15

Berdasarkan uji korelasi antara persentase PADTP dengan persentase gizi buruk (gambar 5), korelasi yang ditunjukkan lemah. Akan tetapi, terdapat kecenderungan semakin tinggi persentase PADTP semakin rendah prevalensi gizi buruknya. Hal ini terlihat di tingkat kabupaten/kota secara nasional maupun di tingkat kawasan. Pendapatan Asli Daerah (PAD) adalah dana 


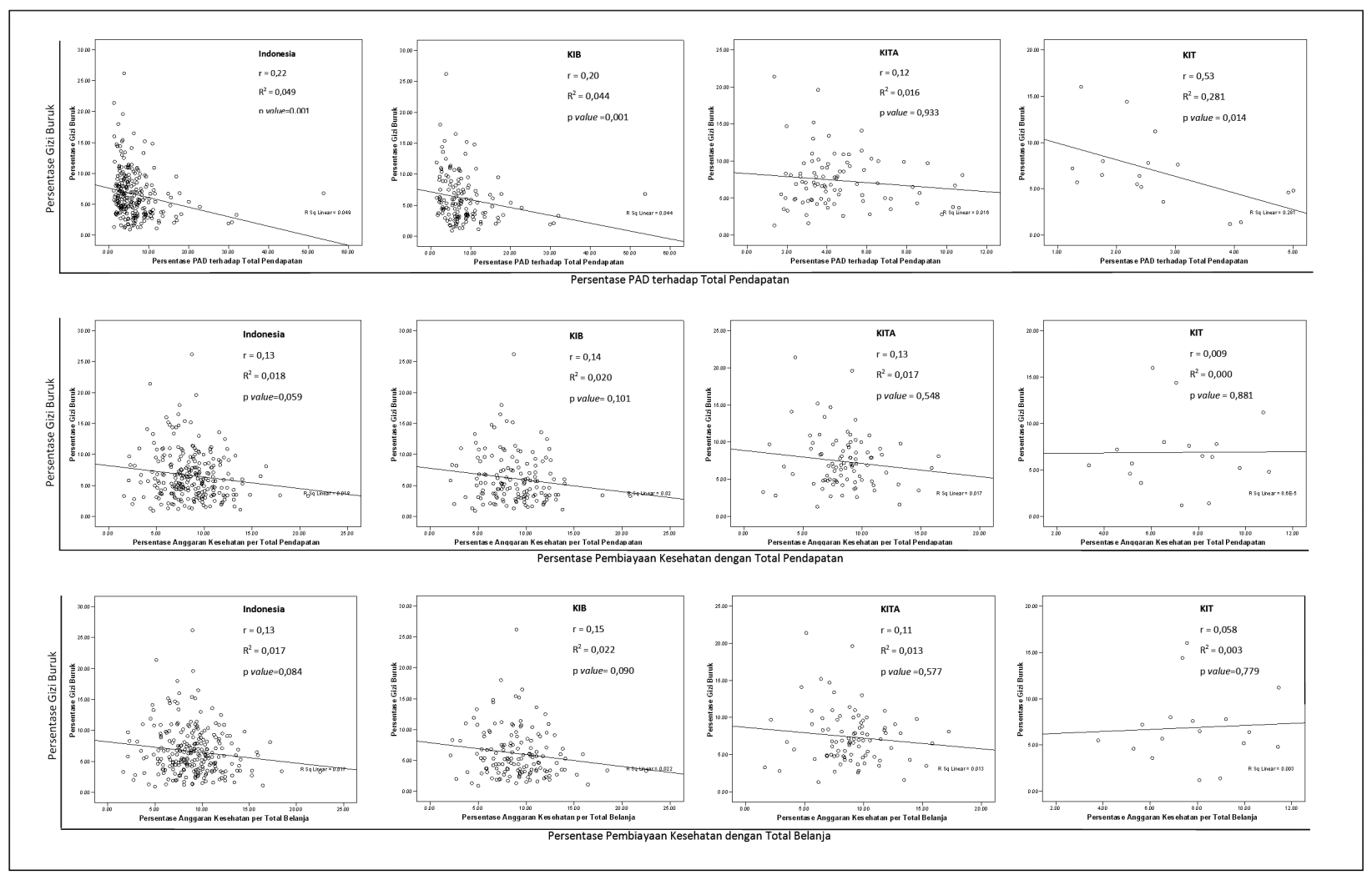

Gambar 5. Korelasi Peran, lase PAD per Total Pendapatan, Pembiayaan Kesehatan per Total Pendapatan, Persentase Pembiayaan Kesehatan per Total Belanja dengan Persentase Gizi Buruk

asli yang berasal dari suatu daerah (kabupaten/kota) dan digunakan/dialokasikan untuk kepentingan dan kebutuhan daerah, tanpa ada campur tangan instansi pemerintah yang lebih tinggi (provinsi atau pusat). ${ }^{11}$ Penelitian tahun 1990 - 2010 yang melibatkan 140 negara dengan menggunakan data sekunder dari 500 survei, menyatakan ada hubungan antara kesenjangan pendapatan antarnegara dan antarpenduduk dengan kesenjangan kesehatan penduduk antar wilayah. ${ }^{16}$

Rata-rata persentase PKTP yaitu 8,53\%. Sedangkan, rata-rata persentase PKTB kabupaten/kota yaitu 8,95\% (tabel 1). Kedua persentase tersebut lebih besar dibandingkan persentase alokasi PKTB pada periode 1994/1995 sampai 2000 yaitu 5,80\%.10 Sementara, dana pembiayaan kesehatan merupakan gabungan dari dana pemerintah pusat dan daerah. Dana dari pemerintah pusat diberikan kepada pemerintah daerah dalam bentuk dana dekonsentrasi, dana alokasi umum, dan dana alokasi khusus nonreboisasi. Penelitian ini memang tidak terdapat data nominal pembiayaan kesehatan berdasarkan sumber pendanaannya. Namun, patut diingat bahwa dana dari berbagai sumber tersebut memiliki ciri penggunaannya masing-masing sehingga meskipun besaran pembiayaan kesehatan di suatu kabupaten/kota besar, penggunaan dana tersebut tidak seutuhnya dapat disesuaikan. ${ }^{11}$
Banyak kabupaten/kota yang persentase PKTP dan persentase PKTB antara 5\% - < 10\% (Gambar 2 dan 3). Hal ini belum memenuhi kesepakatan Bupati/Walikota se-Indonesia tahun 2000 dan TAP MPR/VI/2002 yang merekomendasikan pembiayaan kesehatan secara bertahap menjadi $15 \%$ dari APBN/APBD. Sedangkan, menurut UU Kesehatan No.36 Tahun 2009, besar anggaran kesehatan pemerintah daerah provinsi dan kabupaten/kota dialokasikan minimal 10\% dari anggaran pendapatan dan belanja daerah di luar gaji. ${ }^{10}$

Tidak terdapat korelasi pada persentase PKTP dan persentase PKTB yang dilihat berdasarkan nilai $\mathrm{p}$ dan nilai $r$ (Gambar 5). Hal ini serupa dengan hasil penelitian Heywood yang menyatakan tidak ada hubungan antara pembiayaan kesehatan di sepuluh kabupaten di Jawa Tengah dan Jawa Timur terhadap output sistem kesehatan. ${ }^{17}$ Namun, penelitian ini memperlihatkan kecenderungan bahwa semakin tinggi persentase PKTP maupun PKTB. Semakin rendah prevalensi gizi buruk, kecuali untuk KIT yang kecenderungannya berbeda.

Tidak terdapat korelasi karena data pembiayaan kesehatan untuk program gizi tidak tersedia dan tidak semua pembiayaan kesehatan digunakan untuk program yang secara langsung maupun tidak langsung berhubungan dengan gizi balita. Berdasarkan Analisis Tim National Heath Account Departemen Kesehatan, pem- 
biayaan kesehatan oleh pemerintah kabupaten/kota tahun 2002-2004 sebagian besar (31\% - 48\%) digunakan untuk membiayai kegiatan administrasi kesehatan pemerintahan umum dan $(17 \%-31 \%)$ untuk kegiatan diklat tenaga kesehatan serta riset. Sementara itu, untuk kegiatan pelayanan preventif dan kesehatan masyarakat hanya sebesar $9,2 \%-11,3 \%$ dari total pembiayaan. ${ }^{18}$ Jika persentase pembiayaan kesehatan kecil, dana yang dialirkan ke pelayanan kesehatan dan dinas kesehatan juga semakin kecil. Akibatnya, bukan tidak mungkin ada pelayanan dan program yang dijalankan secara tidak optimal. Hal ini menguatkan mengapa aspek pembiayaan terutama pembiayaan kesehatan dikaitkan dengan status kesehatan, seperti yang digambarkan Jeugmans bahwa pembiayaan kesehatan yang tidak optimal berdampak pada nutrisi masyarakat yang kualitasnya menurun. ${ }^{19}$

Pendapat lain mengemukakan bahwa terdapat beberapa masalah jika menggunakan pendekatan 15\% dari APBD. Untuk daerah miskin dengan PAD rendah dan alokasi anggaran pusat terbatas, angka 15\% dari APBD akan menyerap cukup banyak anggaran daerah untuk kesehatan sehingga alokasi di sektor lain tidak cukup. Sebaliknya, bagi daerah dengan penghasilan besar, 15\% dari APBD akan melampaui kebutuhan riil sektor kesehatan sehingga terjadi anggaran belanja yang berlebih. Oleh karena itu, penting untuk menentukan berapa besar biaya kesehatan yang dibutuhkan untuk pelaksanaan program dan kebutuhan penduduk. Health accounting yang komprehensif menjadi penting untuk terciptanya sinkronisasi perencanaan dan pembiayaan kesehatan karena pembiayaan kesehatan yang rendah mengakibatkan konsep dan infrastruktur yang sebenarnya cukup baik tidak bisa berfungsi secara optimal. ${ }^{20}$ Pembiayaan kesehatan bersumber pemerintah yang rendah juga dikaitkan dengan pengeluaran masyarakat yang tinggi untuk menutupi kebutuhan kesehatan. Hal inilah menyebabkan ketidakmerataan pada masyarakat dan berdampak pada kesehatan kelompok rentan, salah satunya balita. 21

Terdapat lima faktor yang diperkirakan dapat menentukan prioritas dan kecukupan alokasi pembiayaan bidang kesehatan, yaitu jumlah penerimaan daerah yang berasal dari pemerintah pusat dan daerah yang tercantum dalam APBD, skala prioritas bidang kesehatan di mata para pimpinan daerah, ${ }^{10,22}$ kemampuan dinas kesehatan dalam melakukan advocay, kemampuan dinas kesehatan untuk menyusun rencana anggaran yang baik, dan kemampuan dinas kesehatan menyajikan informasi alur pendanaan kesehatan daerah termasuk informasi sumber-sumber dana yang ada sampai bagaimana penggunaan dana tersebut terhadap pencapaian program-program kesehatan. ${ }^{10,20,23}$ Sebuah studi yang menggunakan data 121 survei yang melibatkan 36 negara berpendapatan rendah dan berpendapatan menengah menye- butkan bahwa pertumbuhan makro-ekonomi memiliki hubungan yang lemah atau bahkan tidak ada dalam hal kaitannya dengan balita pendek (stunting), berat rendah (underweight) dan gizi buruk (wasting). Fakta yang ditemukan meliputi pendapatan yang meningkat belum dipastikan terdistribusi dengan merata, serta dimanfaatkan dengan memperbaiki status gizi maupun untuk membangun fasilitas publik yang terkait dengan peningkatan status gizi balita. ${ }^{22}$

Pada kenyataannya, selain besaran dana kesehatan, persentasenya terhadap total pendapatan maupun total belanja, hal yang lebih penting adalah pemanfaatan dana dengan efisien dan efektif. Dana-dana kesehatan yang besar tidak secara otomatis dapat meningkatkan derajat kesehatan. Pemanfaatan dana inilah yang lebih berperan dalam meningkatkan derajat kesehatan. Dengan kata lain, pembiayaan kesehatan is necessary but insufficient dalam meningkatkan derajat kesehatan. ${ }^{24,25}$ Oleh karena itu, pemanfaatan pembiayaan kesehatan yang optimal menjadi penting karena jika dibandingkan kerugian ekonomi akibat produktivitas yang menurun karena gizi buruk, penanggulangan dini seperti biaya pemberian PMT pada balita jauh lebih kecil. ${ }^{7}$

Keterbatasan penelitian ini adalah terdapat kabupaten/kota yang datanya tidak lengkap (karena tidak melaporkan data ke pusat) maupun tidak valid sehingga penelitian ini tidak dapat menggambarkan kabupaten/kota yang 'dikeluarkan' dari penelitian seperti yang disebutkan dalam kriteria eksklusi. Selain itu, gambaran pendapatan daerah, pembiayaan kesehatan dan gizi buruk pada studi ini tidak dapat menggambarkan hubungan yang terjadi pada level individu. Data pembiayaan kesehatan yang tersedia hanya total alokasi dan realisasi untuk sektor kesehatan, sementara data rinci tiap program kesehatan hanya tersedia di masing-masing Dinas Kesehatan Kabupaten/Kota dan tidak dimungkinkan untuk diakses seluruhnya. Penelitian ini hanya mengorelasikan total pembiayaan kesehatan dengan gizi buruk, bukan pembiayaan khusus program gizi dengan gizi buruk. Persentase/besar pembiayaan untuk program gizi terhadap total pembiayaan kesehatan dan sumber-sumber pembiayaan kesehatan juga tidak diketahui sehingga persentase pendapatan asli daerah yang dialokasikan untuk pembiayaan kesehatan tidak ketahui. Padahal, data tersebut dapat melihat seberapa besar (kabupaten/kota) pemerintah daerah memprioritaskan sektor kesehatannya. Selain itu, analisis statistik yang digunakan adalah korelasi sehingga tidak dapat menjelaskan adanya variabel perancu (confounding) dan efek modifikasi.

\section{Kesimpulan}

Secara keseluruhan di kabupaten/kota di Indonesia, terdapat kecenderungan semakin tinggi persentase PADTP, PKTP dan PKTB, semakin rendah prevalensi gizi 
buruknya (dalam arti luas, semakin baik status kesehatannya). Korelasi yang diperlihatkan sangat lemah karena pada kenyataannya banyak "hal diantara" PAD, pembiayaan kesehatan dan gizi buruk (status kesehatan) yang patut diperhatikan, yaitu komitmen pemerintah terhadap bidang kesehatan, perencanaan dan pengalokasian dana sesuai kebutuhan penduduk dan wilayah, pemanfaatan dana yang efisien, pembiayaan dan penyediaan pelayanan kesehatan (termasuk rasio pelayanan kesehatan dengan penduduk, rasio tenaga kesehatan, pelayanan kesehatan terkait program gizi dan program prioritas lainnya), serta pemerataan pembiayaan sesuai kebutuhan penduduk. Dengan kata lain, pembiayaan kesehatan tetap menjadi faktor yang penting meskipun meningkatkan pembiayaan saja tidak cukup untuk meningkatkan derajat kesehatan.

\section{Saran}

Penelitian mengenai pendanaan/pembiayaan dengan status kesehatan di Indonesia masih terbatas sehingga masih dapat dikembangkan penelitian yang membahas "hal diantara" pembiayaan dan kesehatan. Penelitian serupa masih memungkinkan untuk dikembangkan dan dianalisis dalam lingkup yang lebih kecil (misalnya berdasarkan kawasan) maupun menganalisis dari segi pembiayaan per program kesehatan dengan masalah kesehatan terkait. Penelitian ini diharapkan dapat menjadi referensi bagi pengembangan penelitian serupa tersebut.

\section{Daftar Pustaka}

1. WHO. World Health Statistic 2007 part 1: Ten statistical highlights in global public health Geneva: WHO; 2007.

2. Direktorat Bina Gizi Masyarakat, Kementerian Kesehatan Republik Indonesia. Pedoman pelaksanaan surveilans gizi di kabupaten/kota. Jakarta: Kementerian Kesehatan Republik Indonesia; 2010.

3. Badan Litbang Kesehatan, Kementerian Kesehatan Republik Indonesia. Laporan Riset Kesehatan Dasar tahun 2007. Jakarta: Kemenkes RI; 2007.

4. Pelletier DL, Frongillo EA. Changes in child survival are strongly associated with changes in malnutrition in developing countries. Journal of Nutrition. 2013 Jan; 133(1):107-19.

5. Ivanovic DM, Levia BP, Perez HT, Inzunza NB, Almagia AF, Toro TD, et al. Long-term effects of severe undernutrition during the first year of life on brain development and learning in Chilean High-School Graduates. Journal of Nutrition. 2000; 16 (11-12):1056-63.

6. Mendez MA, Adair LS. Severity and timing of stunting in the first two years of life affect performance on cognitive test in late childhood. Journal of Nutrition. 1999 Aug; 129 (8): 1555-62.

7. Aries M, Martianto D. Estimasi kerugian ekonomi akibat status gizi buruk dan biaya penanggulangannya pada balita di berbagai provinsi di Indonesia. Jurnal Gizi dan Pangan. 2006 Nov; 1(2): 26-33.

8. Utomo B. Dampak krisis moneter dan kekeringan terhadap status kese- hatan dan gizi anak. Dalam: PPT-LIPI UNICEF, ed. Prihatin lahir batin: dampak krisis moneter dan bencana El-Nino terhadap masyarakat, keluarga, ibu dan anak di Indonesia dan pilihan intervensi. Jakarta: PPT-LIPI; 1998. p. 133-45.

9. WHO. The World Health report. Health systems: improving performance. Geneva: WHO; 2000.

10. Thabrany $\mathrm{H}$, editor. Pendanaan kesehatan dan alternatif mobilisasi dana kesehatan di Indonesia. Jakarta: PT RajaGrafindo Persada; 2005.

11. Murti B, Trisnanto L, Probandari A. Perencanaan dan penganggaran untuk investasi kesehatan di tingkat kabupaten dan kota. Yogyakarta: Gajah Mada University Press; 2006.

12. Mukaka MM. Statistics corner: a guide to appropriate use of correlation coefficient in medical research. Malawi Medical Journal. 2012 Sept; 24 (3): 69-71.

13. Peraturan Menteri Keuangan [Internet]. Departemen Keuangan Web site. 2006 [diakses tanggal 15 Juli 2011]. Diunduh dalam: http://www.sjdih.depkeu.go.id/fulltext/2006/72 PMK.02 2006Per.ht $\mathrm{m}$.

14. World Health Organization. Training course on child growth assessment: module c interpreting growth indicator. Geneva: WHO; 2008.

15. Heywood P, Harahap NP. Public funding on health at the district level in Indonesia after decentralization - sources, flows, and contradictions. Journal of Health Research Policy and Systems. 2009 April 16; 7(5).

16. Johns NE, Cowling K, Gakidou E. The wealth (and health) of nations: a cross-country analysis of the relation between wealth and inequality in disease burden estimation. The Lancet. 2013 June; 381 (S66).

17. Heywood P, Choi Y. Health system performance at the district level in Indonesia after decentralization. BMC International Health and Human Rights Journal. 2010 March; 10 (3).

18. Pusat Pembiayaan dan Jaminan Kesehatan, Depkes RI. Analisis pembiayaan kesehatan nasional. Jakarta: Depkes RI; 2008.

19. Jeugmans J. Economic crisis and health of the poor : evidence matters. In South East Asia Regional Conference on Epidemiology; 8-10 March 2010; New Delhi. New Delhi: World Health Organization; 2010.

20. Budiarto W, Ristrini. Kontribusi anggaran pemerintah dalam pembiayaan program kesehatan pada era otonomi daerah. Jurnal Manajemen Pelayanan Kesehatan. 2003; 6(4): 215-25.

21. Anderson I, Axelson H, Tan BK. The other crisis: the economics and financing of maternal, newborn and child health in Asia. Health Policy and Planning. 2011; 26 (4): 288-97.

22. Vollmer S, Harttgen K, Subramanyam MA, Finlay J, Klasen S, Subramanian SV. Association between economic growth and early childhood undernutrition: evidence from 121 demographic and health survey from 36 low-income and middle-income countries. The Lancet Global Health. 2014 April; 2: 225-34.

23. Sukarna, Ahmad LO, Budiningsih N, Riyarto S. Analisis kesiapan dinas kesehatan dalam mengalokasikan anggaran kesehatan pada era desentralisasi. Jurnal Manajemen Pelayanan Kesehatan. 2006; 9 (1): 10-8.

24. Sachs JD. Macroeconomic and Health: investing in health for economic development. Report of the commission on macroeconomics and health. Geneva: World Health Report; 2001.

25. Hsiao WC. Why is a systematic view of health financing necessary? Health Affairs Journal. 2007; 26(4): 950-61. 